\title{
Characterizing the pathotype of neonatal meningitis causing Escherichia coli (NMEC)
}

\begin{abstract}
Background: Neonatal meningitis-causing Escherichia coli (NMEC) is the predominant Gram-negative bacterial pathogen associated with meningitis in newborn infants. High levels of heterogeneity and diversity have been observed in the repertoire of virulence traits and other characteristics among strains of NMEC making it difficult to define the NMEC pathotype. The objective of the present study was to identify genotypic and phenotypic characteristics of NMEC that can be used to distinguish them from commensal E. coli.
\end{abstract}

Methods: A total of 53 isolates of NMEC obtained from neonates with meningitis and 48 isolates of fecal $E$. coli obtained from healthy individuals (HFEC) were comparatively evaluated using five phenotypic (serotyping, serum bactericidal assay, biofilm assay, antimicorbial susceptibility testing, and in vitro cell invasion assay) and three genotypic (phylogrouping, virulence genotyping, and pulsed-field gel electrophoresis) methods.

Results: A majority (67.92 \%) of NMEC belonged to B2 phylogenetic group whereas $59 \%$ of HFEC belonged to groups $A$ and $D$. Serotyping revealed that the most common $\mathrm{O}$ and $\mathrm{H}$ types present in NMEC tested were $\mathrm{O} 1$ (15\%), O8 (11.3\%), O18 (13.2\%), and H7 (25.3\%). In contrast, none of the HFEC tested belonged to 01 or 018 serogroups. The most common serogroup identified in HFEC was O8 (6.25\%). The virulence genotyping reflected that more than $70 \%$ of NMEC carried kpsll, K1, neuC, iucC, sitA, and vat genes with only less than $27 \%$ of HFEC possessing these genes. All NMEC and $79 \%$ of HFEC tested were able to invade human cerebral microvascular endothelial cells. No statistically significant difference was observed in the serum resistance phenotype between NMEC and HFEC. The NMEC strains demonstrated a greater ability to form biofilms in Luria Bertani broth medium than did HFEC (79.2 \% vs $39.9 \%)$.

Conclusion: The results of our study demonstrated that virulence genotyping and phylogrouping may assist in defining the potential NMEC pathotype.

Keywords: Biofilms, Escherichia coli, Genotyping, Invasion assay, Neonatal meningitis, Serotyping, Virulence

\section{Background}

Escherichia coli is a versatile bacterial species that exists as a commensal in the lower gastrointestinal tract of humans and animals as well as a pathogen that causes a variety of diseases $[1,2]$. Unlike commensal $E$. coli, pathogenic $E$. coli harbor various virulence genes which provide the basis for categorizing them into different pathovars with each pathovar having the ability to establish a distinct

\footnotetext{
* Correspondence: sxk91@psu.edu

${ }^{1}$ Department of Veterinary and Biomedical Sciences, Pennsylvania State University, 115 Henning Bldg, University Park, Pennsylvania, USA

${ }^{7}$ Center for Molecular Immunology and Infectious Disease, Pennsylvania

State University, University Park, Pennsylvania, USA

Full list of author information is available at the end of the article
}

infection [1]. These virulence traits include adhesins, iron acquisition systems, toxins, invasins, and serum resistant components of the cell wall that are encoded by the bacterial chromosome and plasmids [1-6].

A distinct pathotype of extra-intestinal pathogenic E. coli (ExPEC) known as neonatal meningitis-causing E. coli (NMEC) have the ability to survive in blood and invade meninges of infants to cause meningitis $[1,7,8]$. Escherichia coli associated neonatal meningitis is one of the most common infections that accounts for high mortality and morbidity rates (10-30 \%) during the neonatal period $[1,9]$. Although distinct sets of virulence traits have been identified in diarrheagenic E. coli and other ExPEC pathovars, 
distinct virulence traits have not been identified to define the NMEC pathotype [10]. Several studies have attempted to characterize NMEC strains using phenotypic and genotyping methods, such as serotyping, multi-locus sequence typing (MLST), phylogrouping, pulsed-field gel electrophoresis (PFGE), antibiotic resistance gene profiling, and virulence genotyping [7, 10-13]. A recent study showed that NMEC strains are diverse in their virulence gene repertoire and the genes that are uniquely associated with NMEC have yet to be identified [10]. Although NMEC have to breach the blood brain barrier (BBB) to reach and infect the meninges, the studies that used various genotypic and phenotypic traits to characterize NMEC have not compared the ability of different NMEC strains to invade the BBB using a model comparable to human brain microvascular endothelial cells. Here, we attempted to determine the genotypic and phenotypic characteristics of NMEC including their ability to invade the $\mathrm{BBB}$ and identify a set of virulence genes that were relatively common in NMEC as compared to fecal E. coli from healthy humans (HFEC).

\section{Results}

\section{Phylogenetic typing of NMEC and HFEC}

All four major phylogenetic lineages (A, B1, B2, and D) were represented by both NMEC and HFEC although the distribution of each lineage among the isolates belonging to two sources (i.e. NMEC and HFEC) (Table 1, Additional file 1: Table S1) was different. Phylogroup B2 was overly represented in NMEC (67.92\%) as compared to HFEC $(29.17 \%)(p<0.0001)$ whereas the phylogroups $\mathrm{A}$ and B1 were more common in HFEC (31.25\% and $12.5 \%$, respectively) than in NMEC $(9.43 \%$ and $3.77 \%$, respectively) ( $p=0.0001$ and $p=0.0225$, respectively). No statistical difference was observed for the distribution of group D between NMEC and HFEC ( $p=0.2395)$.

\section{Serotyping}

Serotyping of NMEC and HFEC isolates (Fig. 1 and Table 2) showed that 18 different $\mathrm{O}$ serogroups were present in NMEC while 19 different $\mathrm{O}$ groups were observed in HFEC. Three isolates of NMEC and six isolates of HFEC were not typeable by the $\mathrm{O}$ antisera used in the

Table 1 Distribution of different phylogroups between neonatal meningitis E. coli (NMEC) and fecal E. coli from healthy individuals (HFEC). A $p<0.05$ reflects a statistical significance

\begin{tabular}{|c|c|c|c|c|}
\hline \multirow[t]{2}{*}{ Strains } & \multicolumn{2}{|c|}{ Phylogroup (\%) } & \multirow[b]{2}{*}{ B2 } & \multirow[b]{2}{*}{ D } \\
\hline & $\bar{A}$ & $\mathrm{~B} 1$ & & \\
\hline NMEC & 9.43 & 3.77 & 67.92 & 18.87 \\
\hline HFEC & 31.25 & 12.5 & 29.17 & 27.08 \\
\hline$p$ value & 0.001 & 0.0225 & $<0.001$ & 0.2359 \\
\hline
\end{tabular}

study. Another four NMEC and two HFEC demonstrated multiple $\mathrm{O}$ antigen types. The most common $\mathrm{O}$ types present in NMEC were O1 $(n=9)$, O8 $(n=6)$, and $\mathrm{O} 18(n=7)$ whereas $\mathrm{O} 20(n=8)$ and $\mathrm{O} 148(n=5)$ were more common in HFEC than the other O types. Similarly, among NMEC strains tested, ten different $\mathrm{H}$ types were observed, $\mathrm{H} 7$ being the most prevalent $(n=24)$. HFEC strains belonged to 19 different $\mathrm{H}$ types with nine isolates demonstrating an $\mathrm{H}$ - negative phenotype.

\section{Serum resistance}

No statistically significant difference in the percentages of serum resistant isolates between NMEC and HFEC (91.82 \pm 2.17 and $90.97 \pm 1.2$, respectively) was observed $(p=0.5172)$.

\section{Virulence genotyping}

The number of virulence traits present in NMEC was higher $(13 \pm 3.84)$ than in HFEC $(5.50 \pm 2.49)$ revealing a considerable variation between the virulence gene profiles of $E$. coli from two different sources (Additional file 1: Table S1). For example, of the 26 VFs examined in the study, the occurrence of 21 genes was significantly higher $(p<0.05)$ in NMEC than in HFEC (Fig. 2 and Table 3). Notably, K1 capsular type, sfa/foc, sat, hlyA/D, iutA, papG III, and afa genes were only represented in NMEC populations, although their occurrence among NMEC isolates was low except for the K1 capsular type. Virulence traits kpsII, sitA, neuC, iucC, and vat were more commonly associated with NMEC than with HFEC (prevalence $>70 \%$ and representation $>2$-folds higher in NMEC than in HFEC). Similar to the observations made by previous studies, some virulence genes that were implicated in the penetration of BBB, such as fimH, $n p l$, and $i b e B$ were equally present in both NMEC and HFEC strains [10]. On the other hand, some virulence genes, such as cnfl and traJ, that were considered to be required for NMEC pathogenesis, were possessed only by a minority of NMEC (cnfl and traJ in $27.45 \%$ and $43.40 \%$ of NMEC, respectively). However, these genes were more frequently observed in NMEC than in HFEC (Table 3).

\section{PFGE}

Out of the NMEC and HFEC isolates tested, only 98 were typeable by PFGE. The HFEC strain 17 and two NMEC isolates (14 and 20) were nontypeable with $\mathrm{Xba \textrm {I }}$ restriction digestion. The typeable isolates demonstrated 86 distinct PFGE fingerprint patterns or pulsotypes (Fig. 1). Of the 86 pulsotypes, 79 were unique and each pattern was present only in one isolate. The other seven pulsotypes were present in two or more isolates of $E$. coli. Not a single pulsotype was shared between NMEC and HFEC. 


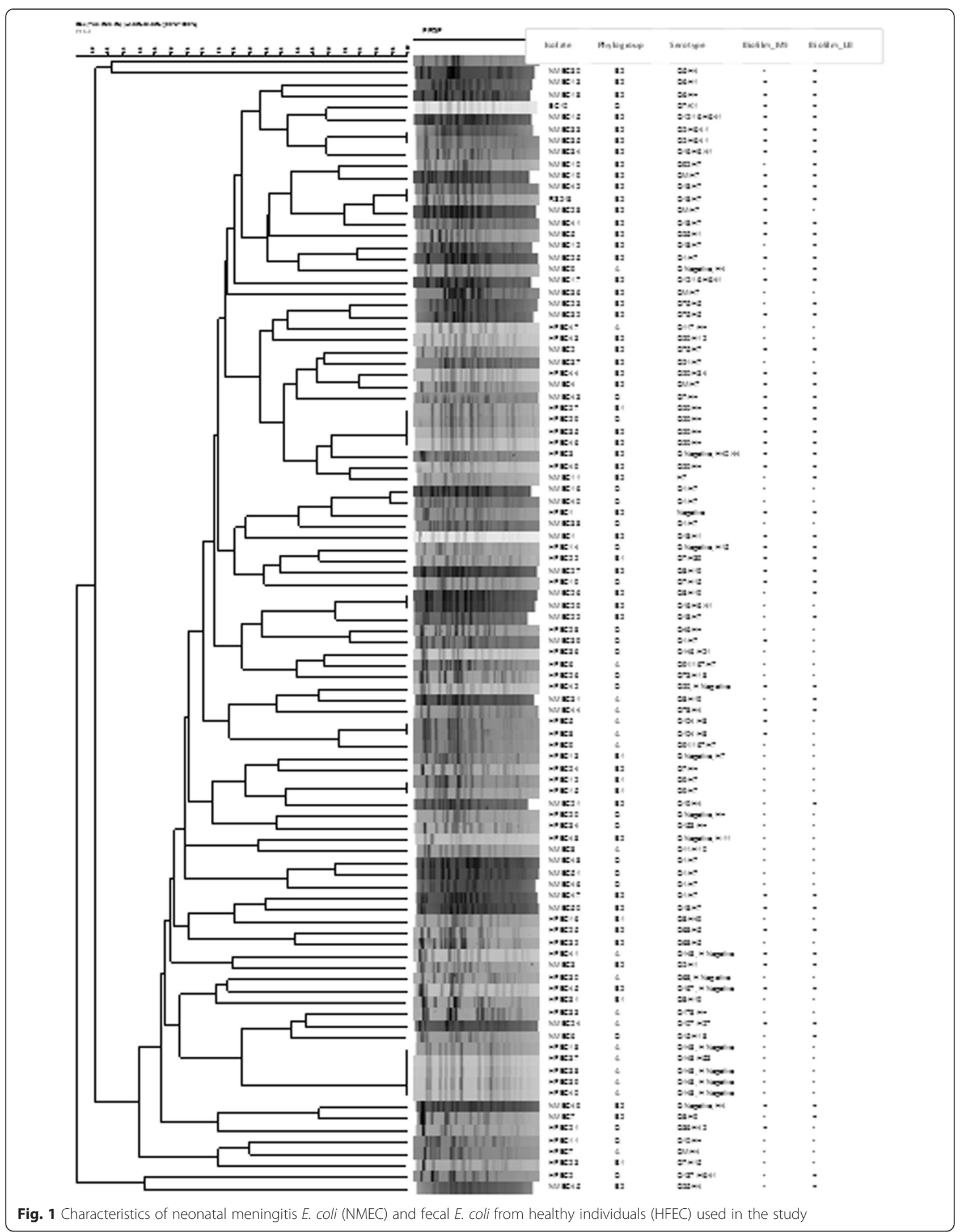


Table 2 Distribution of $\mathrm{O}$ and $\mathrm{H}$ antigen types among NMEC and HFEC strains

\begin{tabular}{|c|c|c|c|c|c|c|c|}
\hline \multicolumn{4}{|l|}{ NMEC } & \multicolumn{4}{|l|}{ HFEC } \\
\hline O Type & No. of Isolates & H Type & No. of Isolates & O Type & No. of Isolates & H Type & No. of Isolates \\
\hline 1 & 9 & 1 & 4 & 7 & 4 & 4 & 1 \\
\hline 2 & 3 & 4 & 6 & 8 & 3 & 5 & 2 \\
\hline 5 & 1 & 5 & 4 & 9 & 2 & 7 & 5 \\
\hline 6 & 2 & 7 & 24 & 10 & 1 & 8 & 2 \\
\hline 7 & 2 & 9 & 1 & 20 & 8 & 11 & 2 \\
\hline 8 & 6 & 10 & 1 & 36 & 1 & 12 & 1 \\
\hline 11 & 1 & 18 & 1 & 38 & 1 & 15 & 3 \\
\hline 15 & 1 & 19 & 3 & 46 & 1 & 18 & 1 \\
\hline 16 & 2 & 27 & 1 & 68 & 3 & 19 & 1 \\
\hline 18 & 7 & $6 / 41$ & 6 & 73 & 1 & 21 & 1 \\
\hline 19 & 1 & POS & 2 & 104 & 2 & 34 & 1 \\
\hline 21 & 1 & & & 117 & 1 & 39 & 1 \\
\hline 25 & 2 & & & 137 & 1 & 42 & 1 \\
\hline 75 & 3 & & & 146 & 1 & 49 & 1 \\
\hline 78 & 1 & & & 148 & 5 & 53 & 1 \\
\hline 92 & 1 & & & 153 & 1 & $6 / 41$ & 1 \\
\hline 107 & 1 & & & 167 & 2 & $40 / 44$ & 1 \\
\hline $12 / 16$ & 2 & & & 178 & 1 & NEG & 9 \\
\hline$M$ & 4 & & & $91 / 167$ & 2 & POS & 13 \\
\hline \multirow[t]{2}{*}{ NEG } & 3 & & & $M$ & 1 & & \\
\hline & & & & NEG & 6 & & \\
\hline
\end{tabular}

M multiple O types, POS positive fliC PCR amplification but untypeable, NEG negative (no agglutination with $\mathrm{O}$ antisera or no flic PCR amplification)

\section{Biofilm assay}

The ability to form biofilms on a microtitre plate by NMEC and HFEC were assessed using M9 minimal medium supplemented with niacin and Luria Bertani (LB) broth (Additional file 1: Table S1). About $53 \%$ of NMEC strains cultured in M9 minimal medium were able to form biofilms on microtitre plates whereas only $39.9 \%$ of HFEC possessed this phenotype (Fig. 1). However, this difference was not statistically significant $(p=1.000)$. A higher percentage of NMEC (79.2\%) formed biofilms when they were cultured in LB broth than in the M9 medium (52.8 \%) but the ability to form biofilms by HEFC remained the same regardless of the medium used.

\section{Antibiotic susceptibility testing and multilocus sequence typing (MLST)}

As depicted in Table 4, a majority of NMEC and HFEC were susceptible to most of the antimicrobials tested in the study. All isolates tested were susceptible to gentamicin, imipenam, meropenem, piperacillin/tazobactam and amikacin. Only five isolates of NMEC and three isolates of HFEC were resistant to all four third generation cephalosporins (cefotaxime, cefpodooxime, ceftazidine and ceftrixone). The minimal inhibitory concentration (MIC) values for these eight isolates were increased by $\geq 3$ folds when cefotaxime and ceftazidine were used in combination with clavulanic acid as compared to the MIC values for cefotaxime and ceftazidine alone confirming that these isolates possessed the ESBL resistance phenotype according to the Clinical Laboratory Standards Institute (CLSI) guidelines. To further characterize E. coli demonstrating an ESBL phenotype, they were subjected to MLST. The eight isolates with an ESBL phenotype fell into eight different sequence types (STs) demonstrating a clonal diversity among the isolates (Table 5).

\section{In-vitro cell invasion assay}

Invasion frequencies between NMEC and HFEC (85.31 \pm 10.60 vs $54.04 \pm 7.0387$, respectively; $p=0.0196)$ displayed a statistically significant difference (Fig. 3). Except ten isolates of HEFC, all other HFEC and NMEC isolates were able to invade human cerebral microvascular endothelial cells (hCMECs) albeit at different invasion frequencies (Additional file 1: Table S1). Some HFEC strains demonstrated invasion frequencies similar to or higher than that of the prototypic NMEC strain RS218. 


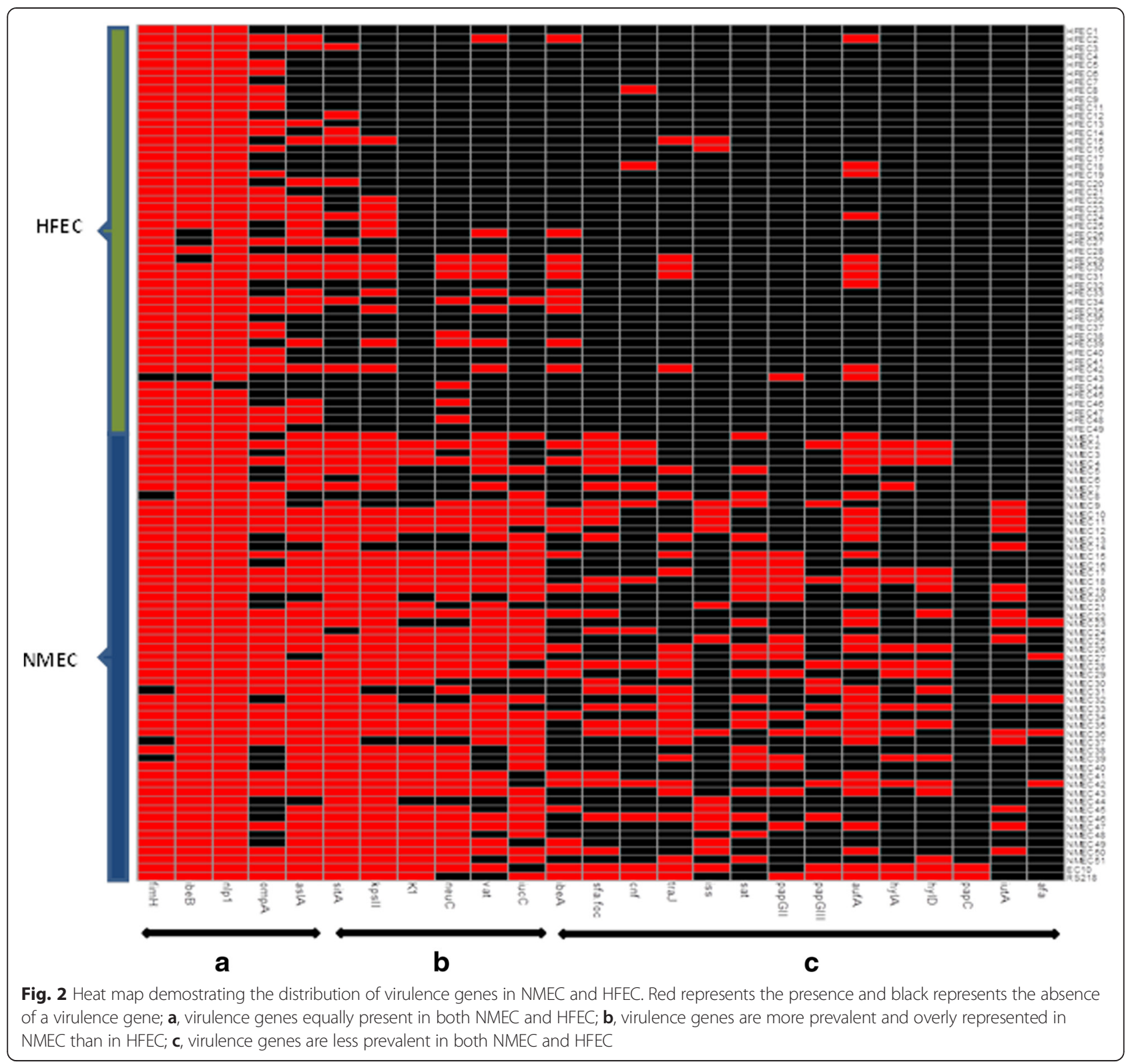

\section{Discussion}

Pathogenic E. coli consist of diarrheagenic E. coli causing intestinal disease and ExPEC causing extraintestinal diseases in humans and animals $[1,2]$. Both diarrheagenic E. coli and ExPEC are grouped into many pathotypes or pathovars depending on the clinical outcome of the disease and virulence properties of $E$. coli involved $[1,11,14]$. Of these two major groups of pathogenic $E$. coli, ExPEC possess the ability to colonize and infect extraintestinal sites of the host by means of horizontally acquired genetic determinants or virulence genes [14]. Several studies have been conducted to identify the unique virulence traits of ExPEC, such as uropathogenic E. coli, NMEC, and avian pathogenic E. coli to understand the genetic makeup and pathogenic potential of different ExPEC pathovars [10-13]. However, these studies indicate that substantial genotypic and phenotypic heterogeneity exist within each pathotype, and a pathotype cannot be defined merely based on the presence of a defined set of virulence genes or characteristics. Nevertheless, some virulence attributes are shared among different pathotypes making it difficult to delineate ExPEC pathotypes $[7,10,12,13,15]$. Here, we comparatively analyzed genotypic and phenotypic traits of NMEC and HFEC to identify the characteristics that would assist in defining the NMEC pathotype.

In this study, we examined a collection of NMEC for the most prevalent ( $>70 \%$ of the NMEC population) and overly represented virulence traits found in NMEC as compared to HFEC ( $>3$-fold) for defining the NMEC 
Table 3 Occurrence (\%) of virulence genes between neonatal meningitis E. coli (NMEC) and fecal E. coli (HFEC)

\begin{tabular}{|c|c|c|c|c|}
\hline Gene & NMEC & HFEC & Chi Square value & $p$ value \\
\hline$a f a$ & 9.43 & 0.00 & 7.446 & 0.0064 \\
\hline as/A & 88.68 & 45.83 & 41.814 & $<0.0001$ \\
\hline aufA & 62.26 & 20.83 & 32.952 & $<0.0001$ \\
\hline$c n f$ & 27.45 & 4.17 & 20.19 & $<0.0001$ \\
\hline $\mathrm{fimH}$ & 92.45 & 100.00 & 6.380 & 0.0115 \\
\hline hly & 30.19 & 0.00 & 32.980 & $<0.0001$ \\
\hline hlyD & 35.85 & 0.00 & 45.995 & $<0.0001$ \\
\hline ibeA & 35.85 & 20.83 & 6.881 & 0.0087 \\
\hline$i b e B$ & 100.00 & 91.67 & 6.380 & 0.0115 \\
\hline iss & 25.49 & 4.17 & 16.132 & $<0.0001$ \\
\hline incC & 74.51 & 2.08 & 109.471 & $<0.0001$ \\
\hline iutA & 30.19 & 0.00 & 32.980 & $<0.0001$ \\
\hline K1 & 75.47 & 0.00 & 116.821 & $<0.0001$ \\
\hline kpsll & 90.57 & 27.08 & 82.038 & $<0.0001$ \\
\hline neuc & 71.70 & 18.75 & 54.522 & $<0.0001$ \\
\hline$n \mid p 1$ & 100.00 & 97.92 & 0.505 & 0.4773 \\
\hline ompA & 66.04 & 60.41 & 0.536 & 0.464 \\
\hline papC & 3.77 & 0.00 & 2.296 & 0.129 \\
\hline papGll & 31.37 & 2.08 & 25.833 & $<0.0001$ \\
\hline papGIII & 21.57 & 0.00 & 22.523 & $<0.0001$ \\
\hline sat & 49.02 & 0.00 & 62.279 & $<0.0001$ \\
\hline$s f a / f o c$ & 49.06 & 0.00 & 62.279 & $<0.0001$ \\
\hline sitA & 92.45 & 25.00 & 89.713 & $<0.0001$ \\
\hline tral & 43.40 & 10.41 & 26.287 & $<0.0001$ \\
\hline vat & 76.47 & 18.75 & 32.829 & $<0.0001$ \\
\hline
\end{tabular}

$p<0.05$ reflects a statistical significance. Virulence genes that were more prevalent in NMEC compared to HFEC are marked in bold

pathotype. Based on these criteria, we have identified six genes, namely, kpsII, $\mathrm{K} 1$, neuC, iucC, sitA, and vat, which were predominantly associated with NMEC pathotype. Among these, some virulence traits such as, kpsII, sitA, and vat are considered as typical traits of NMEC [10]. None of the HFEC isolates surveyed possessed all six genes, whereas $40 \%$ of NMEC isolates harbored all six genes suggesting that these genes might be used to predict the NMEC pathotype (Fig. 4). As depicted in Fig. 4, a majority of NMEC possessed the K1 capsular type $(n=76 \%)$. All $\mathrm{K}^{+} \mathrm{NMEC}$ were positive for sitA together with vat and/or iucC. Except three isolates, all other $\mathrm{K}^{+}$ NMEC harbored the neuC gene as well. Taken together, these results suggest that a typical NMEC might be described as $\mathrm{K}^{+}$and $s i t A^{+}$and having at least two of the other three genes; vat, neuC and iucC. Using this criterion, it was possible to designate $74 \%$ of NMEC used in this study as typical NMEC whereas none of the HFEC satisfied these benchmarks. However, typing of a larger collection of NMEC isolates representing different geographical regions might be required to confirm these observations.

A PCR-based phylogrouping has been established to determine the clonality within E. coli pathotypes [16, 17]. Previous studies have identified group B2 as the most common phylogroup of ExPEC suggesting that phylogrouping may be used as a rapid typing method to identify potential ExPEC $[10,12,14,18]$. In the present study, we observed that $67.9 \%$ of NMEC fell into B2 phylogroup as compared to $29.2 \%$ of HFEC tested in the study. Phylogroups A and B1 were more commonly associated with HFEC than with NMEC. The virulence gene profiles of NMEC strains belonging to each phylogroup lineage exhibited a higher prevalence of virulence genes as compared to HFEC strains belonging to the corresponding lineage (Table 6). Taken together, our observations emphasize that phylogrouping alone is not suitable for predicting potential NMEC.

Pulsotyping and serotyping have been used in various studies to identify pathogenic clones and to distinguish between pathogenic and nonpathogenic strains of many bacterial species $[7,19,20]$. In our study, we observed a considerable heterogeneity among both NMEC and HFEC. As depicted in Table 2, despite this diversity, many NMEC strains belonged to $\mathrm{O} 1, \mathrm{O} 8$, and $\mathrm{O} 18$ serogroups and $\mathrm{H} 7$ flagellar antigen type. Similar to our observation, previous studies have also noted that the $\mathrm{H} 7$ antigen is present in major virulent clones of ExPEC pathotypes making it a potential target for future diagnostic and therapeutic interventions [21, 22]. Two subtypes of $\mathrm{H} 7$ antigen have been identified for enterohemorrhagic E. coli (EHEC) based on the flic $(\mathrm{H} 7)$ allelic polymorphism, a technique which possibly can be used to type EHEC [23, 24]. For example, $\mathrm{H} 7 \mathrm{a}$ and H7c subtypes have been identified in E. coli O157: $\mathrm{H} 7$ irrespective of their geographical origin and genetic variation observed with other molecular typing methods [23]. However, whether this genetic polymorphism of H7 does or does not exist in ExPEC pathotypes is currently unknown. Future studies focused on H7 allelic polymorphism of ExPEC may provide useful information to develop a novel subtyping technique to distinguish different ExPEC pathovars. The heterogeneity observed with PFGE was even greater than serotyping indicating that PFGE is not useful in distinguishing NMEC strains from HFEC.

Ability to form biofilms in different environmental conditions facilitates bacterial survival on abiotic surfaces and their resistance to antimicrobials and antiseptics $[25,26]$. Given that biofilm formation is reported to assist in bacterial survival, colonization, and protection from host immune responses and antimicrobial agents, the ability to produce biofilms may play an important role in NMEC virulence [25-27]. Therefore, we compared the capacity 
Table 4 Antibiotic susceptibility profiles of NMEC and HFEC. Number of isolates (stated as percentages) in NMEC and HFEC were categorized as Sensitive (S), Intermediate (I) or Resistant (R) according to CLSI standards

\begin{tabular}{|c|c|c|c|c|c|c|}
\hline \multirow[t]{2}{*}{ Antibiotic } & \multicolumn{3}{|l|}{ NMEC } & \multicolumn{3}{|l|}{ HFEC } \\
\hline & S & । & $\mathrm{R}$ & S & । & $\mathrm{R}$ \\
\hline Ampicillin & 50.94 & 3.773585 & 45.28 & 64.58 & 4.167 & 31.25 \\
\hline Cefazolin & 96.23 & 0 & 3.77 & 93.75 & 0 & 6.25 \\
\hline Cefepime & 96.23 & 0 & 3.77 & 100 & 0 & 0 \\
\hline Cefotaxime & 90.57 & 0 & 9.43 & 93.75 & 0 & 6.25 \\
\hline Cefoxitin & 90.57 & 0 & 9.43 & 95.83 & 2.08 & 2.08 \\
\hline Cefpodoxime & 90.57 & 0 & 9.43 & 9.16 & 0 & 8.33 \\
\hline Ceftazidime & 90.57 & 0 & 9.43 & 93.75 & 0 & 6.25 \\
\hline Ceftriaxone & 88.68 & 1 & 9.43 & 91.66 & 2.08 & 6.25 \\
\hline Cephalothin & 100 & 0 & 0 & 100 & 0 & 1 \\
\hline Ciprofloxacin & 100 & 0 & 0 & 100 & 0 & 0 \\
\hline Gentamicin & 100 & 0 & 0 & 100 & 0 & 0 \\
\hline Imipenem & 100 & 0 & 0 & 100 & 0 & 0 \\
\hline Meropenem & 100 & 0 & 0 & 100 & 0 & 0 \\
\hline Piperacillin/Tazobactam & 100 & 0 & 0 & 100 & 0 & 0 \\
\hline Ceftazidime/Clavulanic acid & 100 & 0 & 0 & 100 & 0 & 0 \\
\hline Amikacin & 100 & 0 & 0 & 100 & 0 & 0 \\
\hline Amoxicillin & 100 & 0 & 0 & 60.41 & 2.083 & 37.5 \\
\hline Chloramphenicol & 94.34 & 0 & 5.66 & 97.91 & 2.083 & 0 \\
\hline Sulfa/Trimethoprim & 81.13 & 0 & 18.86 & 93.75 & 0 & 6.25 \\
\hline Kanamycin & 86.79 & 2 & 9.433 & 100 & 0 & 0 \\
\hline Nalidixic acid & 96.23 & 0 & 3.773 & 81.25 & 0 & 18.75 \\
\hline Sulfisoxazole & 67.92 & 3 & 14 & 68.75 & 16.66 & 14.58 \\
\hline Tetracycline & 81.13 & 0 & 10 & 91.66 & 0 & 8.33 \\
\hline
\end{tabular}

for biofilm formation by NMEC and HFEC. There was no significant difference in the ability of biofilm formation between NMEC and HFEC isolates when they were grown in M9 medium. However, when LB broth was used as the medium, NMEC demonstrated approximately $39 \%$ increase in their ability to form biofilms. In consistent with our observations, previous studies have demonstrated that growth medium has an effect on biofilm formation by pathogenic bacteria $[28,29]$. Jackson et al. noted that central carbon flux has a regulatory effect on the formation of biofilms [28]. In particular, readily available glucose has a negative regulatory effect on biofilm formation suggesting that the ability to form biofilms is a survival strategy by bacteria when the source of carbon is limited or complex

Table 5 Serotypes and multilocus sequence types (ST) of ESBL-positive isolates

\begin{tabular}{|c|c|c|c|c|c|c|c|c|c|}
\hline \multirow[t]{2}{*}{ Isolate } & \multirow[t]{2}{*}{ Serotype } & \multicolumn{7}{|c|}{ Multilocus sequence alleles } & \multirow[t]{2}{*}{ ST } \\
\hline & & $a d k$ & fumC & gyrB & $i c d$ & $m d h$ & purA & $\operatorname{rec} A$ & \\
\hline NMEC2 & $\mathrm{O} 75: \mathrm{H7}$ & 40 & 20 & 19 & 14 & 23 & 1 & 10 & ST843 \\
\hline NMEC3 & $\mathrm{O} 2: \mathrm{H} 1$ & 36 & 24 & 9 & 13 & 17 & 11 & 25 & ST73 \\
\hline NMEC44 & $\mathrm{O} 78: \mathrm{H} 4$ & 6 & 4 & 12 & 1 & 20 & 13 & 7 & ST23 \\
\hline NMEC46 & $\mathrm{O} 1: \mathrm{H7}$ & 27 & 32 & 24 & 29 & 26 & 19 & 22 & ST59 \\
\hline NMEC50 & $\mathrm{O} 18: \mathrm{H7}$ & 37 & 38 & 19 & 37 & 17 & 11 & 26 & ST95 \\
\hline HFEC2 & O137:H6/41 & 13 & 14 & 19 & 22 & 17 & 14 & 203 & ST2678 \\
\hline HFEC9 & O167:H7 & 6 & 4 & 5 & 18 & & 8 & 14 & Unknown ST \\
\hline $\mathrm{HFEC} 13^{\mathrm{a}}$ & $\mathrm{H} 7$ & 6 & 19 & 3 & 16 & 11 & 8 & 173 & Unknown ST \\
\hline
\end{tabular}

${ }^{a}$ No agglutination with $\mathrm{O}$ antisera 


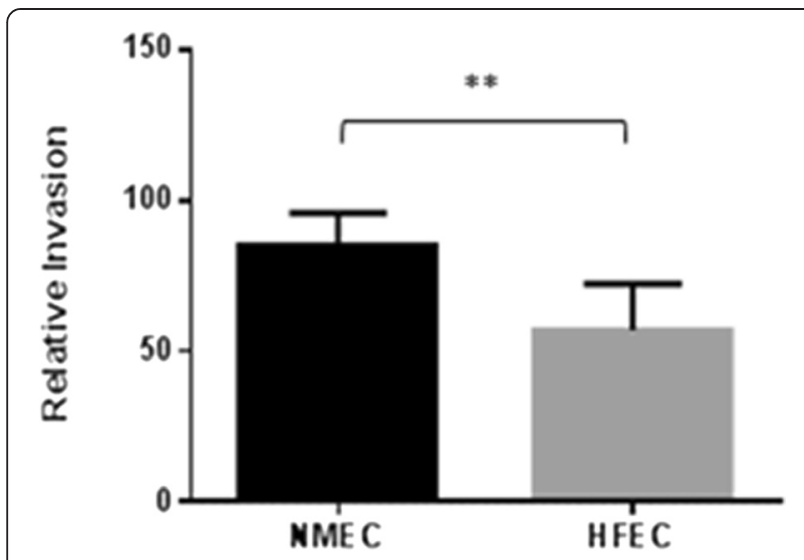

Fig. 3 Relative invasion frequencies observed between NMEC and HFEC populations. **Denotes a statistically significant difference $(p<0.05)$

[28]. The M9 medium contained $2 \%$ glucose which is a readily available carbon source whereas in LB broth catabolizable amino acids are the source carbon source for bacterial growth. Increase in biofilm formation by NMEC in LB broth as compared to M9 medium might be due to readily available glucose in M9 medium suggesting that the source of carbon has an effect on biofilm formation by NMEC but not by HFEC.

Beta-lactam antibiotics are one of the major treatment options available for controlling meningitis in infant patients [30]. We evaluated the antibiotic sensitivity profiles of NMEC and HFEC along with ESBL resistance profiles. Although the majority of strains were sensitive to most of the antibiotics tested, eight isolates showed an ESBLresistance phenotype. Interestingly, three of the ESBL- resistant isolates were fecal commensal isolates implying fecal flora as a source for the emergence of ESBL-resistance. Previous studies have indicated an association between ESBL types and MLST types [31]. The ESBL-positive E. coli identified in this study fell into ST73, ST23, and ST59 MLST types, which are known to contain E. coli possessing certain ESBL types. However, none of the ESBL-positive E. coli detected here did belong to ST131, a major MLST type associated with ESBL-positive E. coli [31]. The ESBL genes are commonly located on mobilizable elements (e g. transposons and broad host range plasmids) and ESBL genes are distributed among commensal microflora of humans and animals [32]. Although a positive correlation between the presence of ESBL-positive HFEC and ESBL-positive UPEC has been observed by many investigators, there is no evidence to suggest an association between the presence of ESBL-producing bacteria in vaginal or fecal flora of pregnant women and corresponding ESBLproducing bacterial infections in neonates [33]. Nevertheless, it has been demonstrated that the risk factors, such as premature delivery, premature membrane rupture, and low birth weight which are known to predispose infants to E. coli meningitis were correlated with the colonization of ESBL-producing Enterobacteriaceae in the infant gut [33].

Genetic heterogeneity of NMEC pathotype is one of the major constraints posing today to understand the pathogenesis of neonatal meningitis [7, 10, 12]. Concordance with these previous studies, we have also observed marked heterogeneity in the virulence gene profiles of NMEC. Although NMEC possessed more virulence genes than HFEC, some of the virulence genes (ibeA, sfal foc, traJ, and cnf1), which have previously been implicated

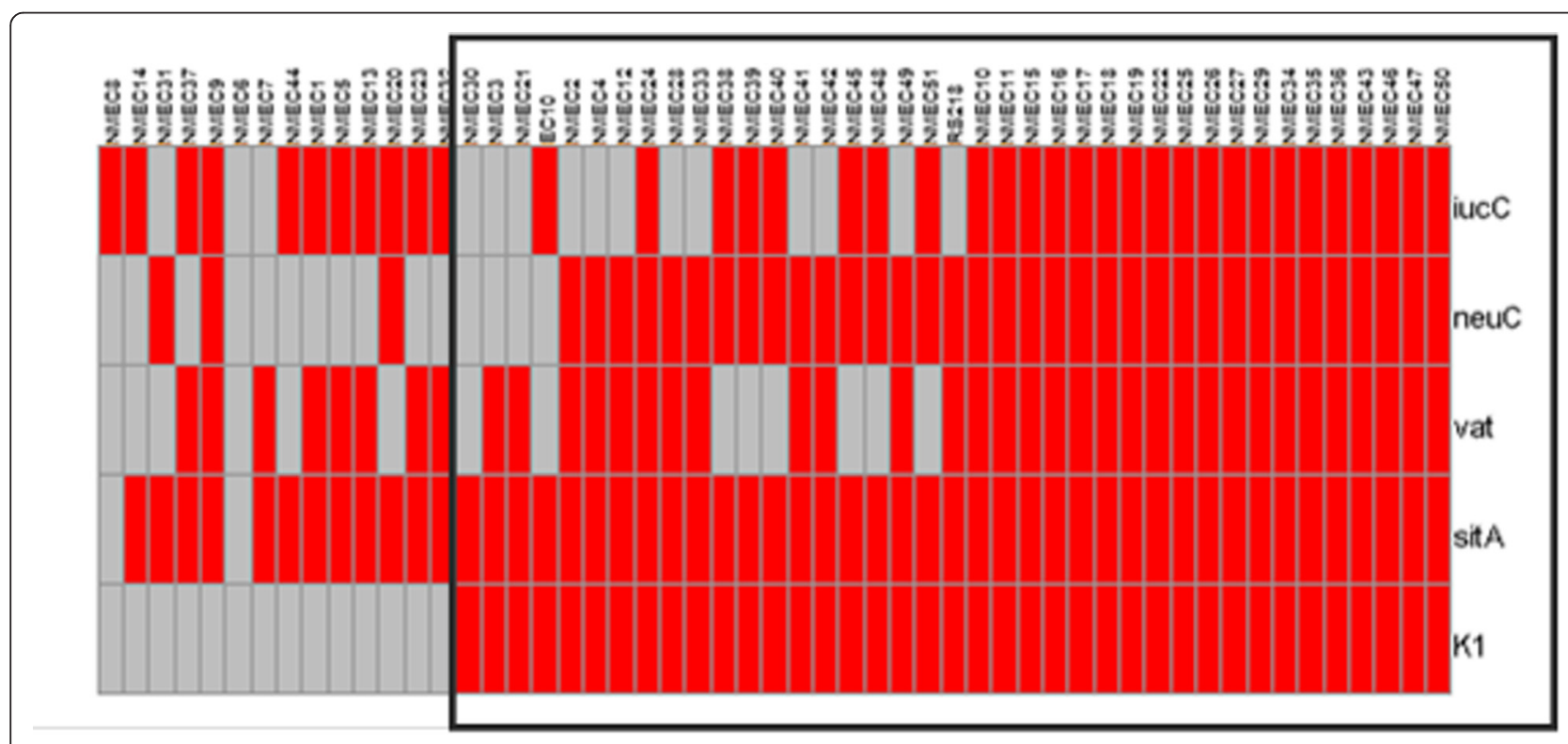

Fig. 4 Distributin of K1, sitA, vat, neuC, and iucC genes among NMEC strains ( $n=53)$. Red, positive for a gene; Grey, negative for a gene. Encircled area indicates the isolates used to define a typical NMEC 
Table 6 Number of virulence traits present in neonatal meningitis E. coli (NMEC) and fecal E. coli (HFEC) belonging to different phylogroups

\begin{tabular}{llll}
\hline Phylogroup & \multicolumn{4}{l}{ No. Virulence associated traits (Mean \pm SD) } & $p$ value \\
\hline & NMEC & HFEC & \\
A & $10 \pm 2.74$ & $5.13 \pm 2.33$ & $0.0011^{\mathrm{a}}$ \\
B1 & $8.0 \pm 2.83$ & $6.5 \pm 3.02$ & 0.5610 \\
B2 & $15.19 \pm 3.21$ & $4.64 \pm 1.95$ & $<0.0001^{\mathrm{a}}$ \\
D & $12.4 \pm 3.92$ & $6.38 \pm 2.79$ & $0.0003^{\mathrm{a}}$ \\
\hline
\end{tabular}

${ }^{\mathrm{a}}$ Denotes a statistically significant difference between NMEC and HFEC

in NMEC pathogenesis were present only in $<50 \%$ of NMEC examined (Fig. 2) [34-36]. The virulence traits, such as fim $H, o m p A$, and $n l p 1$ that are considered to be essential for NMEC survival in blood and the penetration of BBB were prevalent in both NMEC and HFEC suggesting these genes do not define the NMEC pathotype [34-39]. The NMEC and HFEC strains that did not harbor these "essential" virulence genes were still able to invade hCMEC/D3. These data indicate that NMEC pathogenicity is poorly understood and highlight the need for future research directed at mining novel virulence traits that are truly involved in the penetration of BBB.

In the present study, NMEC strains harbored genes that encode iron acquisition systems (iut $A$, iuc $C$, and $\operatorname{sit} A$ ) and hemolysins ( $h l y A$ and $h l y D)$, which were more frequently present in NMEC than in HFEC. In addition to providing a source of iron for bacterial growth through cell lysis, bacterial hemolysins are known to play some other mechanistic roles as well [40]. For example, sublytic amounts of E. coli hemolysin have been shown to increase the permeability of endothelial cell monolayers in a time- and dosedependent manner in cultured pulmonary artery endothelial cells [40]. In the same study, a low dose of hemolysin was found to induce a toxin-mediated loss of endothelial barrier function. However, there is no scientific evidence to support the involvement of hemolysins of NMEC in increasing the permeability of BBB thereby aiding the disease pathogenesis.

In this study, an in vitro invasion assay was conducted to correlate the virulence traits of each isolate of $E$. coli with its ability to penetrate the BBB. As expected, NMEC strains which carried more virulence genes than HFEC were also more invasive in hCMEC/D3 cells than HFEC (Fig. 3). Interestingly, ten isolates of HFEC which demonstrated a noninvasive phenotype with in vitro cell invasion assay were negative for $\mathrm{K} 1$ capsular type, ibeA, traJ, and $s f a / f o c$ but were positive for fimH, ibeB, and $n l p l$ indicating that ibeA, traJ, and $s f a / f o c$ may be important in NMEC pathogenesis even though their occurrence in NMEC was less than some other virulence genes. Except these ten noninvasive isolates, all other HFEC were able to invade the $\mathrm{BBB}$ barrier in vitro suggesting fecal commensal $E$. coli as a potential source of NMEC. It is known that a high level of bacteremia is a prerequisite for the attachment and invasion of BBB by NMEC $[9,41]$. The present study also demonstrated that NMEC and HFEC were equally able to survive in human serum, supporting the speculation that commensal $E$. coli in the mother's gut could be a source for NMEC in the baby. Perhaps serum resistance of NMEC may not be as important as previously thought because neonatal serum is deficient in many complement factors. It would be worthy to compare the survival potential of NMEC in serum collected from healthy adults and neonates. Further investigations on HFEC strains exhibiting invasive properties using animal models of meningitis may be needed to confirm that HFEC indeed have the potential to cause neonatal meningitis.

\section{Conclusions}

The current study results indicate that regardless of the genotypic and phenotypic heterogeneity observed among NMEC strains, some genotypic characteristics can still be used to distinguish NMEC from commensal $E$. coli.

\section{Materials and methods}

\section{Bacterial strains and media}

The NMEC comprised of 51 strains isolated from the cerebrospinal fluid of neonates with meningitis plus two well-characterized NMEC strains, RS218 (O18:K1:H7) and EC10 (O7: K1). The RS218 [42] and EC10 [43, 44] strains isolated from the cerebrospinal fluid of neonates with meningitis in the 1970's were kindly provided by Dr. James Johnson, University of Minnesota, St. Paul, MN, USA and Dr. David Klumpp, Northwestern University, Evanston, IL, USA, respectively. Other NMEC strains $(n=51)$ isolated between 1989 and 1997 from patients in the United States were provided by Dr. K. S. Kim, Johns Hopkins University School of Medicine, Baltimore, Maryland, USA $[10,42]$. Fecal E. coli $(n=48)$ isolated from feces of healthy individuals (HFEC) were obtained from the E. coli Reference Center collection (Pennsylvania State University, University, Park, PA, USA). These isolates were collected during the period between 1985 and 2005 from healthy individuals in two states of the U.S., New York and Pennsylvania. Unless otherwise mentioned, all the bacterial strains were grown in Luria Bertani (LB) broth (BD Technologies, Research Triangle Park, NC, USA) or LB agar (BD Technologies).

\section{Phylogrouping of $E$. coli}

All strains were assigned to four main phylogenetic groups; A, B1, B2 and D according to the method described by Clemont et al. [17]. Classification of phylogenetic groups was based on the amplification of two genes, chuA and 
Table 7 Primers used in the study

\begin{tabular}{|c|c|c|c|c|}
\hline Primer Name & Gene/Function & Sequence $5^{\prime}-3^{\prime}$ & Product size & Reference \\
\hline chuA.1 & Phylogrouping & GACGAACCAACGGTCAGGAT & 279 & {$[17]$} \\
\hline chuA.2 & & TGCCGCCAGTACCAAAGACA & & \\
\hline yjaA.1 & Phylogrouping & TGAAGTGTCAGGAGACGCTG & 211 & {$[17]$} \\
\hline yjaA.2 & & ATGGAGAATGCGTTCCTCAAC & & \\
\hline TspE4C2.1 & Phylogrouping & GAGTAATGTCGGGGCATTCA & 152 & {$[17]$} \\
\hline TspE4C2.2 & & CGCGCCAACAAAGTATTACG & & \\
\hline afaF & Afimbrial adhesin & CAT CAA GCT GTT TGT TCG TCC GCC G & 750 & {$[52]$} \\
\hline afaR & & GCT GGG CAG CAA ACT GAT AAC TCT C & & \\
\hline asIAF & Arylsulfatase & GCG TGA TGT TCA TGT CAA CC & 463 & [44] \\
\hline asIAR & & ATC CGC CAG ATC TAC AAT GC & & \\
\hline aufAF & Auf fimbriae & TGC ACA TCA GGA AAC CAG ATA C & 350 & This study \\
\hline aufR & & GGC TCA CTG ATA TGG ATG ACA A & & \\
\hline $\mathrm{cnfF}$ & Cytotoxic necrotizing factor 1 & CAT TCA GAG TCC TGC CCT CAT TAT T & 498 & [53] \\
\hline $\mathrm{cnfR}$ & & AAG ATG GAG TाT CCT ATG CAG GAG & & \\
\hline fimHF & Type I fimbriae & GCA GTC ACC TGC CCT CCG GTA & 508 & [53] \\
\hline fimHR & & TGC AGA ACG GAT AAG CCG TGG & & \\
\hline hlyAF & Alpha hemolysin & ACC ATA TAA GCG GTC ATT CCC GTC A & 1177 & [53] \\
\hline hlyAR & & AAC AAG GAT AAG CAC TGT TCT GGC T & & \\
\hline hlyDF & Secretion protein for HlyA & CTC CGG TAC GTG AAA AGG AC & 904 & [54] \\
\hline hlyDR & & GCC CTG ATT ACT GAA GCC TG & & \\
\hline ibeAF & Invasin of brain endothelium A & CAT TAG CTC TCG GTT CAC GCT & 171 & {$[55]$} \\
\hline ibeAR & & TTA CCG CCG TTG ATG TTA TCA & & \\
\hline ibeBF & Invasin of brain endothelium B & GCA TATTCTGCTGGTITCTAATGTC & 660 & This study \\
\hline ibeBR & & GTT CTG GAT TIT CTG TTC ATA ATT CA & & \\
\hline issF & Increased serum survival & CAG CAA CCC GAA CCA CTT GAT G & 323 & [54] \\
\hline issR & & AGC ATT GCC AGA GCG GCA GAA & & \\
\hline iutAF & Aerobactin synthesis & ATGAGCATATCTCCGGACG & 587 & {$[52]$} \\
\hline iutAR & & CAGGTCGAAGAACATCTGG & & \\
\hline iucCF & Aerobactin synthesis & ACC CGT CTG CAA ATC ATG GAT & 269 & [55] \\
\hline iucCR & & AAA CCT GGC TTA CGC AAC TGT & & \\
\hline sitAF & Periplasmic iron-binding protein & AGG GGG CAC AAC TGA TTC TCG & 608 & {$[56]$} \\
\hline sitAR & & TAC CGG GCC GTT TTC TGT GC & & \\
\hline kpsMTII F & Capsular type II & GCG CAT TTG CTG ATA CTG TTG & 272 & {$[57]$} \\
\hline kpsMT IIR & & CAT CCA GAC GAT AAG CAT GAG CA & & \\
\hline kpsMT K1 & K 1 capsule & TAG CAA ACG TTC TAT TGG TGC & 153 & {$[57]$} \\
\hline kpsMT IIR & & CAT CCA GAC GAT AAG CAT GAG CA & & {$[57]$} \\
\hline neuCF & Capsular N-acetylneuraminic acid synthesis & GGT GGT ACA TTC CGG GAT GTC & 676 & {$[52]$} \\
\hline neuCR & & AGG TGA AAA GCC TGG TAG TGT G & & \\
\hline Nlp I F & New lipoprotein I (adhesin/invasin) & AGT AAT ACT TCC TGG CGT AAA AGT GA & 662 & This study \\
\hline$N|p| R$ & & AAA TAG AAG TTG GTT TCA CTG AGA TG & & \\
\hline ompAF & Outer membrane protein $\mathrm{A}$ & CACTAAATCCAACGTTIATGGTAAAA & & This study \\
\hline ompAR & & GATACCTTTAACTTCGATCTCTACGC & & \\
\hline papCF & Outer membrane usher protein of $\mathrm{P}$ pili & ATA TCC TाT CTG CAG GGA TGC AAT A & 205 & {$[57]$} \\
\hline
\end{tabular}


Table 7 Primers used in the study (Continued)

\begin{tabular}{|c|c|c|c|c|}
\hline \multicolumn{2}{|l|}{$\overline{p a p C R}$} & \multicolumn{3}{|l|}{ GAC GGC TGT ACT GCA GGG TGT GGC G } \\
\hline papG IF & Fimbrial adhesin PapG allele I & CTA CTA TAG TTC ATG CTC AGG TC & 474 & [54] \\
\hline papG IR & & CCT GCA TCC TCC ACC ATT ATC GA & & \\
\hline papG $\| F$ & Fimbrial adhesin PapG allele ॥ & CCC AGC TTT GTT ATT TTC CTT G & 190 & {$[54]$} \\
\hline papGIIR & & TTC TTA CCA TGG CTG TAT GTC G & & \\
\hline papGIIIF & Fimbrial adhesin PapG allele III & GGC CTG CAA TGG ATT TAC CTG G & 258 & [54] \\
\hline papGIIIR & & CCA CCA AAT GAC CAT GCC AGA C & & \\
\hline satF & Secreted autotransporter toxin & GCAGCAAATATTGATATATCA & 630 & [58] \\
\hline satR & & GTTGTTGACCTCAGCAAGGAA & & \\
\hline $\mathrm{sfa} / \mathrm{focF}$ & S fimbrial adhesin & CGG AGG AGT AAT TAC AAA CCT GGC A & 410 & {$[57]$} \\
\hline $\mathrm{sfa} / \mathrm{focR}$ & & CTC CGG AGA ACT GGG TGC ATC TTA C & & \\
\hline trajF & Conjugal transfer & CAA TGG GGC TIT TAT TGA ACT C & 369 & This study \\
\hline trajR & & TGA CCA ACA CCC AGC ATA TAA A & & \\
\hline vat1 & Vacuolating cytotoxin & TCC TGG GAC ATA ATG GTC AG & 900 & This study \\
\hline vat2 & & GTG TCA GAA CGG AAT TGT & & \\
\hline adkF & MLST & ATTCTGCTTGGCGCTCCGGG & 583 & [49] \\
\hline $\operatorname{adkR}$ & & CCGTCAACTTTCGCGTATTT & & \\
\hline fumCF & MLST & TCACAGGTCGCCAGCGCTTC & 806 & [49] \\
\hline fumR & & GTACGCAGCGAAAAAGATT & & \\
\hline gyrBF & MLST & TCGGCGACACGGATGACGGC & 911 & [49] \\
\hline gyrBR & & GTCCATGTAGGCGTTCAGGG & & \\
\hline$i c d F$ & MLST & ATGGAAAGTAAAGTAGTTGTTCCGGCACA & 878 & [49] \\
\hline $\mathrm{icdR}$ & & GGACGCAGCAGGATCTGTT & & \\
\hline mdhF & MLST & ATGAAAGTCGCAGTCCTCGGCGCTGCTGGCGG & 932 & [49] \\
\hline mdhR & & TTAACGAACTCCTGCCCCAGAGCGATATCTTTCTT & & \\
\hline purAF & MLST & TCGGTAACGGTGTTGTGCTG & 816 & [49] \\
\hline purAR & & CATACGGTAAGCCACGCAGA & & \\
\hline recAF & MLST & CGCATTCGCTTTACCCTGACC & 780 & [49] \\
\hline recAR & & TCGTCGAAATCTACGGACCGGA & & \\
\hline
\end{tabular}

$y j a A$ and the DNA fragment, TspE4C2 by using a multiplex polymerase chain reaction (PCR) assay. The primers used are listed in Table 7.

\section{Serotyping}

Serotyping was performed at the E. coli Reference Center (Pennsylvania State University) using a standard serum agglutination assay for the presence of all designated $\mathrm{O}$ groups (O1 to O187 except O13, O22, O31, O47 and O94 that are not designated) and $\mathrm{H}$ types ( $\mathrm{H} 1$ to $\mathrm{H} 56)$ [45].

\section{Serum resistance}

Survival of bacterial strains (both NMEC and HFEC) in normal human serum (EMD Millipore Corporation, Temecula, CA, USA) was determined by colorimetric microassay as previously described [46]. Briefly, log phase cultures of bacterial strains were incubated for $3 \mathrm{~h}$ at $42{ }^{\circ} \mathrm{C}$ in Peptone/Glucose broth containing $0.75 \%$ bromothymol blue with or without $20 \%$ normal human serum (NHS). Serum resistance of each strain was determined by comparing the color change from green to yellow in the presence of NHS.

\section{Virulence typing of $E$. coli}

NMEC and HFEC strains were examined for the presence of 26 genes encoding virulence factors (VFs) that have been previously attributed to the establishment of meningitis in neonates $[1,9]$. The VFs included adhesins, invasins, toxins, siderophores, and structural components of E. coli. Virulence genes were detected by PCR amplification carried out on a Master Cycler Pro (Eppendorf, Hamburg, Germany). All primers were obtained from Integrated DNA Technologies (Coralville, IA, USA) and are listed in Table 7. Crude DNA was extracted by a rapid 
boiling method [47]. All PCRs were performed in 25- $\mu \mathrm{l}$ reactions containing $1 \mathrm{U}$ of Taq DNA polymerase (Denville Scientific Inc., Metuchen, NJ, USA), 25 pmol each of the forward and reverse primers, and $5 \mathrm{nmol}$ of each deoxynucleoside triphosphate (Denville) in $1 \times$ buffer $(15 \mathrm{mM}$ $\mathrm{MgCl}_{2}, 100 \mathrm{mM} \mathrm{KCl}, 80 \mathrm{mM}\left(\mathrm{NH}_{4}\right)_{2} \mathrm{SO}_{4}, 100 \mathrm{mM}$ Tris- $\mathrm{HCl}, \mathrm{pH}$ 9.0, $0.5 \% \mathrm{NP}-40$ ). The cycling conditions were as follows: initial denaturation at $94{ }^{\circ} \mathrm{C}$ for $3 \mathrm{~min}$, followed by 30 cycles of three steps consisting denaturation at $94{ }^{\circ} \mathrm{C}$ for $1 \mathrm{~min}$, primer annealing at the temperatures indicated in Table 7 for $1 \mathrm{~min}$, and extension at $72{ }^{\circ} \mathrm{C}$ for at least $30 \mathrm{~s}$, according to the size of the amplified fragment ( $1 \mathrm{~min} / \mathrm{Kbp})$, and followed by a final extension at $72{ }^{\circ} \mathrm{C}$ for $10 \mathrm{~min}$. Products were electrophoresed in a $1.5 \%$ agarose gel (Denville) for $1 \mathrm{~h}$ at $120 \mathrm{~V}$, stained with ethidium bromide (Bio-Rad Laboratories, Hercules, CA, USA), and photographed under UV light using a gel documentation system (AlphaImager ${ }^{\circ} \mathrm{HP}$, Alpha Innotech Corporation, San Leandro, CA, USA). Each PCR included a negative control that contained all reagents except template DNA and a positive control that contained an E. coli that is known to carry the respective virulence gene.

\section{Pulsed-field gel electrophoresis}

PFGE was conducted according to the method described by PulseNet [48]. Chromosomal DNA was digested with the $\mathrm{XbaI}$ restriction enzyme. The electrophoresis was performed using a CHEF DRII system (Bio-Rad, Marnes-la-Coquette, France) and the conditions consisted of an initial time of $2.2 \mathrm{~s}$, a final time of $54.2 \mathrm{~s}$ at a gradient of $6 \mathrm{~V} \mathrm{~cm}^{-1}$ and an included angle of $120^{\circ}$. The gels were electrophoresed for $24 \mathrm{~h}$. Salmonella enterica serotype Braenderup strain H9812 (ATCC BAA664, Manassas, VA, USA) was used as a molecular weight standard. A dendrogram was constructed using the Dice similarity coefficient and the unweightedpair group method by average linkages (UPGMA) or neighbor joining algorithm with $3 \%$ position tolerance using Bionumerics 4.0 software (Applied Maths, Austin, Texas, USA).

\section{Biofilm assay}

Qualitative biofilm assay was performed following the procedure described previously [27]. Briefly, overnight bacterial cultures were diluted to 1:100 in M9 minimal medium (BD Technologies) containing $10 \mu \mathrm{g} / \mathrm{ml}$ niacin or LB medium followed by inoculation into U-bottom 96-well plates (Denville) in triplicates. The plates were incubated at room temperature for $24 \mathrm{~h}$ at $37{ }^{\circ} \mathrm{C}$. The plates were washed three times with distilled water and biofilms were stained with $0.1 \%$ crystal violet for $15 \mathrm{~min}$. After three washes with distilled water, the presences or absence of biofilms was evaluated.

\section{Antibiotic susceptibility testing}

Kirby-Bauer (KB) disk diffusion assay was conducted to determine antibiotic resistance profiles using antibiotic paper disks (BD Technologies). The antibiotics used in $\mathrm{KB}$ test were amikacin $(30 \mu \mathrm{g})$, amoxicillin with clavulanic acid $(20 / 10 \mu \mathrm{g})$, chloramphenicol $(30 \mu \mathrm{g})$, kanamycin $(30 \mu \mathrm{g})$, nalidixic acid $(30 \mu \mathrm{g})$, sulfamethoxazole with trimethoprim $(23.75 / 1.25 \mu \mathrm{g})$, sulfisoxazole $(0.25 \mu \mathrm{g})$, and tetracycline $(30 \mu \mathrm{g})$. Susceptibility or resistance profiles were interpreted according to Clinical Laboratory Standards Institute (CLSI) guidelines. Extended spectrum $\beta$-lactamase (ESBL) sensitivity profiles were screened using confirmatory ESBL plates according to manufacturer's instructions (Sensititre; Thermo Fisher Scientific, Oakwood Village, OH, USA). The dilution range of antibiotic concentrations used were as follows; cefazolin $(8-16 \mu \mathrm{g} / \mathrm{ml})$, cefepime $(1-16 \mu \mathrm{g} / \mathrm{ml})$, cefoxitin (4-64 $\mu \mathrm{g} / \mathrm{ml})$, meropenem $(1-8 \mu \mathrm{g} / \mathrm{ml})$, cephalothin $(8-16 \mu \mathrm{g} / \mathrm{ml})$, cefpodoxime $(0.5-64 \mu \mathrm{g} / \mathrm{ml})$, ceftriaxone $(1-128 \mu \mathrm{g} / \mathrm{ml})$, ciprofloxacin $(1-2 \mu \mathrm{g} / \mathrm{ml})$, gentamicin $(4-16 \mu \mathrm{g} / \mathrm{ml})$, ampicillin $(8-16 \mu \mathrm{g} / \mathrm{ml})$, imipenem $(0.5-$ $16 \mu \mathrm{g} / \mathrm{ml})$, piperacillin/tazobactam $(4 / 4-64 / 4 \mu \mathrm{g} / \mathrm{ml})$, ceftazidime $(0.25-128 \mu \mathrm{g} / \mathrm{ml})$, ceftazidime/clavulanic Acid $(0.25 / 4-128 / 4 \quad \mathrm{l} \mu \mathrm{g} / \mathrm{ml})$ and cefotaxime $(0.25-$ $64 \mu \mathrm{g} / \mathrm{ml})$. Plates were incubated at $37^{\circ} \mathrm{C}$ for $18 \mathrm{~h}$ and read automatically using Sensititre System (Thermo Fisher Scientific).

\section{Multilocus sequence typing}

Multilocus sequence typing (MLST) of ESBL-positive $E$. coli isolates was performed using seven housekeeping genes ( $a d k$, fumC, gyrB, icd, $m d h$, purA, and rec $A$ ), as described previously [49]. Primer sequences were obtained from the E. coli MLST database website (http://mlst.ucc.ie/mlst/dbs/Ecoli) (Table 7). The cycling conditions were as follows: initial denaturation at $95{ }^{\circ} \mathrm{C}$ for $5 \mathrm{~min}$, followed by 30 cycles of initial denaturation at $95{ }^{\circ} \mathrm{C}$ for $30 \mathrm{~s}$, primer annealing at the melting temperatures for $30 \mathrm{~s}$, and extension at $72{ }^{\circ} \mathrm{C}$ $1 \mathrm{~min}$ and followed by a final extension at $72{ }^{\circ} \mathrm{C}$ for $10 \mathrm{~min}$. The PCR products were treated with exonuclease I and shrimp alkaline phosphatase (Affymetrix, Santa Clara, CA, USA) and sequenced at the Genomics Core Facility (Penn State University) with the same primers used to generate PCR products. Sequences were compared with E. coli MLST database website to determine the MLST types.

\section{In-vitro cell invasion assay}

The hCMEC/D3 cell line, which is known to possess the main characteristics of primary brain endothelial cells, was kindly provided by Dr. Babette Weksler at Weill Cornell Medical College (New York, NY, USA) [50]. Invasion assays were performed in triplicates using the 
method described previously [51]. Briefly, hCMEC/D3 cells were seeded on 96-well tissue culture plates coated with rat collagen (R\&D Systems, Inc., Minneapolis, MN, USA) and maintained at $37{ }^{\circ} \mathrm{C}$ for six days in a humidified chamber containing $5 \% \mathrm{CO}_{2}$ to form a confluent monolayer. The complete medium used for culturing of hCMEC/D3 cells was EBM-2 endothelial basal medium (Lonza, Allendale, NJ, USA) containing $5 \%$ bovine serum (GE Healthcare Bio-Sciences, Pittsburgh, PA, USA), $1.4 \mu \mathrm{M}$ hydrocortisone (Sigma-Aldrich, St. Louis, MO, USA), $5 \mu \mathrm{g} / \mathrm{ml}$ ascorbic acid (Sigma), $1 \%$ chemically defined lipid concentrate (Invitrogen, Carlsbad, CA, USA), $10 \mathrm{mM}$ HEPES (GE Healthcare Bio-Sciences), and $1 \mathrm{ng} / \mathrm{ml}$ human basic fibroblast growth factor (Sigma). Cells were infected with $E$. coli strains with a multiplicity of infection (MOI) of 100 (100 bacteria per hCMEC/D3) and incubated for 2 hours at $37{ }^{\circ} \mathrm{C}$ in $5 \% \mathrm{CO}_{2}$. Cells were then washed with phosphate-buffered saline (PBS, $\mathrm{pH} 7$ ) three times and incubated with fresh complete EBM-2 medium containing $100 \mu \mathrm{g} / \mathrm{ml}$ gentamicin (Sigma) for one hour to kill extracellular bacteria. Subsequently, $0.2 \mathrm{ml}$ of $0.01 \%$ Triton X-100 (Sigma) was added to each well to release intracellular bacteria. Cells were fully disrupted by repeated pipetting and viable bacteria were enumerated by plating onto LB agar. Invasion frequencies were calculated comparing the ratio between the number of colony forming units (CFU) released from the cells and the number of CFU inoculated per well. To standardize the comparison of invasion frequencies, relative invasion was calculated as a percent of invasion in comparison to the well-characterized NMEC strain RS218, which was arbitrarily set at $100 \%$.

\section{Ethics statement}

Both NMEC and HFEC isolates, in their entirety, were collected for purposes other than this study and were given without any Health Insurance Portability and Accountability Act (HIPAA) identifiers by Dr. K.S. Kim (Johns Hopkins University, Baltimore, MD, USA) and Dr. C. DebRoy (E. coli Reference Center, University Park, PA, USA).

\section{Statistical analysis}

Data were statistically analyzed by Fisher's exact test (virulence genotyping and phylogrouping), two-tailed student's $\mathrm{t}$-test (invasion frequency), and a $p<0.05$ was considered statistically significant. The heat map of virulence gene profiles was constructed using the R code (version 3.1.1).

\section{Availability of supporting data}

The raw data supporting the results of this article are provided in the Additional file 1: Table S1.

\section{Additional file}

Additional file 1: Table S1. Distribution of phylogroups, virulence genes, ability to form biofilms, and relative invasion frequencies of NMEC and HFEC isolates. Detailed procedure for each experiment is included in the Materials and Methods section. Raw data of phylogroups, virulence genes, ability to form biofilms, and invasion frequencies observed with in vitro invasion assays for $E$. coli isolates used in the study are summarized in Additional file 1: Table S1. (XLSX 27 kb)

\section{Abbreviations}

BBB: Blood brain barrier; CFU: Colony forming units; CLSI: Clinical Laboratory Standards Institute; ESBL: Extended spectrum $\beta$-lactamase; ExPEC: Extraintestinal pathogenic E. coli; hCMEC: Human cerebral microvascular endothelial cells; HEPES: 4-(2-hydroxyethyl)-1-piperazineethanesulfonic acid; HFEC: Healthy fecal E. coli; MLST: Multi-locus sequence typing; NMEC: Neonatal meningitis-causing E. coli; PBS: Phosphate buffered saline; PCR: Polymerase chain reaction; PFGE: Pulsed-field gel electrophoresis; UPEC: Uropathogenic E. coli; VFs: Virulence factors.

\section{Competing interests}

The authors declare that they have no competing interests.

\section{Authors' contributions}

DSSW performed most of the laboratory work, interpretation of results, and drafting the manuscript. SG helped with in vitro invasion assays. CD provided fecal E. coli strains, performed E. coli serotyping, and revised the manuscript. KSK provided NMEC strains and revised the manuscript. POC, IAR and BW provided the hCMEC/D3 cell line and helped with cell culture assays. BW revised the manuscript. SK designed the study, assisted in interpreting the data, and helped to draft the manuscript. All authors read and approved the final manuscript.

\section{Acknowledgements}

This research was supported by start-up funds to S.K. from the Department of Veterinary and Biomedical Sciences at the Pennsylvania State University.

\section{Author details}

${ }^{1}$ Department of Veterinary and Biomedical Sciences, Pennsylvania State University, 115 Henning Bldg, University Park, Pennsylvania, USA. ${ }^{2}$ E. coli Reference Center, Department of Veterinary and Biomedical Sciences, Pennsylvania State University, University Park, Pennsylvania, USA. ${ }^{3}$ Division of Pediatric Infectious Diseases, Johns Hopkins University School of Medicine, Baltimore, Maryland, USA. ${ }^{4}$ Department of Cell Biology, University of Paris Descartes, Paris, France. ${ }^{5}$ Department of Biological Sciences, Open University, Milton Keynes, UK. ${ }^{6}$ Department of Medicine, Weill Cornell Medical College in New York, New York, USA. ${ }^{7}$ Center for Molecular Immunology and Infectious Disease, Pennsylvania State University, University Park, Pennsylvania, USA.

Received: 11 May 2015 Accepted: 2 October 2015

Published online: 14 October 2015

\section{References}

1. Kaper JB. Pathogenic Escherichia coli. Nat Rev Microbiol. 2004;2:123-40.

2. Croxen MA, Finlay BB. Molecular mechanisms of Escherichia coli pathogenicity. Nat Rev Micro. 2010;8:26-38.

3. Smith JL, Fratamico PM, Gunther NW. Extraintestinal pathogenic Escherichia coli. Foodborne Pathog Dis. 2007;4:134-63.

4. Johnson JR. Extraintestinal pathogenic Escherichia coli: the other bad E. coli. J Lab Clin Med. 2002;139:155-62.

5. Johnson TJ, Nolan LK. Pathogenomics of the virulence plasmids of Escherichia coli. Microbiol Mol Biol Rev. 2009;73:750-74.

6. Wijetunge DSS, Karunathilake KHEM, Chaudhari A, Katani R, Dudley EG, Kapur V, et al. Complete nucleotide sequence of pRS218, a large virulence plasmid, that augments pathogenic potential of meningitis-associated Escherichia coli strain RS218. BMC Microbiol. 2014;14:203.

7. Bonacorsi S, Bingen E. Molecular epidemiology of Escherichia coli causing neonatal meningitis. Int J Med Microbiol. 2005;295:373-81. 
8. Glode MP, Sutton A, Moxon ER, Robbins JB. Pathogenesis of neonatal Escherichia coli meningitis: induction of bacteremia and meningitis in infant rats fed E. coli K1. Infect Immun. 1977;16:75-80

9. Kim KS. Pathogenesis of bacterial meningitis: from bacteraemia to neuronal injury. Nat Rev Neurosci. 2003;4:376-85.

10. Logue CM, Doetkott C, Mangiamele P, Wannemuehler YM, Johnson TJ, Tivendale KA, et al. Genotypic and phenotypic traits that distinguish neonatal meningitis-associated Escherichia coli from fecal E. coli isolates of healthy human hosts. Appl Environ Microbiol. 2012;78:5824-30.

11. Bingen E. Phylogenetic analysis of strains causing neonatal meningitis suggests horizontal gene transfer from a predominant pool of highly virulent B2 group strains. J Infect Dis. 1998;177:642-50.

12. Johnson J, Oswald E, O'Bryan T, Kuskowsk iM, Spanjaard L. Phylogenetic distribution of virulence associated genes among isolates associated with neonatal bacterial meningitis in the Netherlands. J Infect Dis. 2002;185:774-84.

13. Johnson TJ, Logue CM, Johnson JR, Kuskowski MA, Sherwood JS, Barnes HJ, et al. Associations between multidrug resistance, plasmid content, and virulence potential among extraintestinal pathogenic and commensal Escherichia coli from humans and poultry. Foodborne Pathog Dis. 2012;9:37-46.

14. Johnson JR, Delavari P, Kuskowski M, Stell AL. Phylogenetic distribution of extraintestinal virulence-associated traits in Escherichia coli. J Infect Dis. 2001;183:78-88.

15. Tivendale KA, Logue CM, Kariyawasam S, Jordan D, Hussein A, Li G, et al. Avian-Pathogenic Escherichia coli strains are similar to neonatal meningitis $E$. coli strains and are able to cause meningitis in the rat model of human disease. Infect Immun. 2010;78:3412-9.

16. Adamus-Bialek W, Wojtasik A, Majchrzak M, Sosnowski M, Parniewski P. (CGG)4-Based PCR as a novel tool for discrimination of uropathogenic Escherichia coli strains: comparison with enterobacterial repetitive intergenic consensus-PCR. J Clin Microbiol. 2009;47:3937-44

17. Clermont O, Bonacorsi S, Bingen E. Rapid and simple determination of the Escherichia coli phylogenetic group. Appl Environ Microbiol. 2000;66:4555-8.

18. Picard B, Garcia JS, Gouriou S, Duriez P, Brahimi N, Bingen E, et al. The link between phylogeny and virulence in Escherichia coli extraintestinal infection. Infect Immun. 1999;67:546-53.

19. Mora A, Lopez C, Dabhi G, Blanco M, Blanco J, Alonso M, et al. Extraintestinal pathogenic Escherichia coli O1:K1:H7/NM from human and avian origin: detection of clonal groups B2 ST95 and D ST59 with different host distribution. BMC Microbiol. 2009;9:132.

20. Liu D. Identification, subtyping and virulence determination of Listeria monocytogenes, an important foodborne pathogen. J Med Microbiol. 2006:55:645-59.

21. Korhonen TK, Valtonen MV, Parkkinen J, Väisänen-Rhen V, Finne J, Orskov F, et al. Serotypes, hemolysin production, and receptor recognition of Escherichia coli strains associated with neonatal sepsis and meningitis. Infect Immun. 1985:48:486-91.

22. Russo TA, Johnson JR. Proposal for a new inclusive designation for extraintestinal pathogenic isolates of Escherichia coli: ExPEC. J Infect Dis. 2000;181:1753-4.

23. Ratiner YA, Salmenlinna S, Eklund M, Keskimaki M, Siitonen A. Serology and genetics of the flagellar antigen of Escherichia coli O157:H7a,7c. J Clin Microbiol. 2003;41:1033-40.

24. Wang L, Rothemund D, Curd H, Reeves PR. Species-wide variation in the Escherichia coli flagellin (H-Antigen) gene. J Bacteriol. 2003;185:2936-43

25. Stewart PS. Antibiotic resistance of bacteria in biofilms. Lancet. 2001;358:135-8.

26. Parsek MR. Bacterial biofilm: an emerging link to disease pathogenesis. Ann Rev Microbiol. 2003;57:677-701.

27. OToole GA. Microtiter dish biofilm formation assay. J Vis Exp. 2011; doi: 10.3791/2437

28. Jackson DW, Simecka JW, Romeo T. Catabolite repression of Escherichia col biofilm formation. J Bacteriol. 2002;184:3406-10.

29. Reisner A, Krogfelt KA, Klein BM, Zechner EL, Molin S. In vitro biofilm formation of commensal and pathogenic Escherichia coli strains: impact of environmental and genetic factors. J Bacteriol. 2006;188:3572-81.

30. Boyer-Mariotte $S$, Duboc P, Bonacorsi S, Lemeland JF, Bingen E, Pinquier D. CTX-M-15-producing Escherichia coli in fatal neonatal meningitis: failure of empirical chemotherapy. J Antimicrob Chemother. 2008;62:1472-4.

31. Oteo J, Diestra K, Juan C, Bautista V, Novais A, Pérez-Vázquez M, et al. Extended-spectrum $\beta$-lactamase-producing Escherichia coli in Spain belong to a large variety of multilocus sequence typing types, including ST10
complex/A, ST23 complex/A and ST131/B2. Intl J Antimicrob Agents. 2009;34:173-6.

32. Poirel L, Naas T, Nordmann P. Genetic support of extended-spectrum B-lactamases. Clin Microbiol Infect. 2008;14:75-81.

33. Duman $M$, Abacioglu $H$, Karaman M, Duman N, Ozkan H. $\beta$-lactam antibiotic resistance in aerobic commensal fecal flora of newborns. Pediatr Int. 2005;47:267-73.

34. Badger JL, Wass CA, Weissman SJ, Kim KS. Application of signature-tagged mutagenesis for identification of Escherichia coli K1 genes that contribute to invasion of human brain microvascular endothelial cells. Infect Immun. 2000;68:5056-61.

35. Chi F, Jong TD, Wang L, Ouyang Y, Wu C, Li W, et al. Vimentin-mediated signalling is required for IbeA+E. coli K1 invasion of human brain microvascular endothelial cells. Biochem J. 2010;427:79-90.

36. Khan NA, Wang Y, Kim KJ, Chung JW, Wass CA, Kim KS. Cytotoxic necrotizing factor-1 contributes to Escherichia coli K1 invasion of the central nervous system. J Biol Chem. 2002;277:15607-12.

37. Teng $\mathrm{CH}$, Cai M, Shin S, Xie Y, Kim KJ, Khan NA, et al. Escherichia coli K1 RS218 interacts with human brain microvascular endothelial cells via type 1 fimbria bacteria in the fimbriated state. Infect Immun. 2005;73:2923-31.

38. Teng C-H, Tseng Y-T, Maruvada R, Pearce D, Xie Y, Paul-Satyaseela M, et al. NIpl contributes to Escherichia coli K1 strain RS218 interaction with human brain microvascular endothelial cells. Infec Immun. 2010;78:3090-6.

39. Prasadarao NV, Wass CA, Weiser JN, Stins MF, Huang SH, Kim KS. Outer membrane protein A of Escherichia coli contributes to invasion of brain microvascular endothelial cells. Infect Immun. 1996;64(1):146-53.

40. Suttorp N, Floer B, Schnittler H, Seeger W, Bhakdi S. Effects of Escherichia coli hemolysin on endothelial cell function. Infect Immun. 1990;58:3796-801

41. Dietzman DE, Fischer GW, Schoenknecht FD. Neonatal Escherichia coli septicemia-bacterial counts in blood. J Pediatr. 1974;85:128-30.

42. Silver RP, Aaronson W, Sutton A, Schneerson R. Comparative analysis of plasmids and some metabolic characteristics of Escherichia coli K1 from diseased and healthy individuals. Infect Immun. 1980;29:200-6.

43. Lu S, Zhang X, Zhu Y, Kim KS, Yang J, Jin Q. Complete genome sequence of the neonatal-meningitis-associated Escherichia coli strain CE10. J Bacteriol. 2011;193:7005

44. Yao Y, Xie Y, Kim KS. Genomic comparison of Escherichia coli K1 strains isolated from the cerebrospinal fluid of patients with meningitis. Infect Immun. 2006;74:2196-206.

45. Orskov I, Orskov F, Jann B, Jann K. Serology, chemistry, and genetics of O and K antigens of Escherichia coli. Bacteriol Rev. 1977:41:667-710.

46. Moll A, Cabello F, Timmis KN. Rapid assay for the determination of bacterial resistance to the lethal activity of serum. FEMS Microbiol Lett. 1979;6:273-6.

47. Queipo-Ortuno MI, De Dios CJ, Macias M, Bravo MJ, Morata P. Preparation of bacterial DNA Template by boiling and effect of immunoglobulin $\mathrm{G}$ as an Inhibitor in real-time PCR for serum samples from patients with brucellosis. Clin Vac Immun. 2008;15:293-6.

48. Swaminathan B, Barrett TJ, Hunter SB, Tauxe RV. PulseNet: the molecular subtyping network for foodborne bacterial disease surveillance. United States Emerg Infect Dis. 2001;7:382-9.

49. Wirth T, Falush D, Lan R, Colles F, Mensa P, Wieler LH, et al. Sex and virulence in Escherichia coli: an evolutionary perspective. Mol Microbiol. 2006:60:1136-51.

50. Weksler BB, Subileau EA, Perrier N, Charneau P, Holloway K, Leveque M, et al. Blood-brain barrier-specific properties of a human adult brain endothelial cell line. FASEB J. 2005;19:1872-4.

51. Germon P, Chen YH, He L, Blanco JE, Brée A, Schouler C, et al. ibeA, a virulence factor of avian pathogenic Escherichia coli. J Microbiol. 2005;151:1179-86.

52. Moulin-Schouleur M, Schouler C, Tailliez P, Kao M-R, Bree A, Germon P, et al. Common Virulence factors and genetic relationships between 018:K1:H7 Escherichia coli isolates of human and avian origin. J Clin Microbiol. 2006:44:3484-92

53. Tiba MR, Yano T, Leite DS. Genotypic characterization of virulence factors in Escherichia coli strains from patients with cystitis. Rev Inst Med Trop Sao Paulo. 2008;50:255-60

54. Rodriguez-Siek KE, Giddings CW, Doetkott C, Johnson TJ, Nolan LK. Characterizing the APEC pathotype. Vet Res. 2005;36:241-56. 
55. Watt S, Lanotte P, Mereghetti L, Moulin-Schouleur M, Picard B, Quentin R. Escherichia coli strains from pregnant women and neonates: intraspecies genetic distribution and prevalence of virulence factors. J Clin Microbiol. 2003:41:1929-35.

56. Runyen-Janecky $\amalg$, Reeves SA, Gonzales EG, Payne SM. Contribution of the Shigella flexneri Sit, luc, and Feo iron acquisition systems to iron acquisition in vitro and in cultured cells. Infect Immun. 2003;71:1919-28.

57. Johnson JR, Stell AL. Extended virulence genotypes of Escherichia coli strains from patients with urosepsis in relation to phylogeny and host compromise. J Infect Dis. 2000;181:261-72.

58. Taddei CR, Moreno AC, Fernandes FA, Montemor LP, Martinez MB. Prevalence of secreted autotransporter toxin gene among diffusely adhering Escherichia coli isolated from stools of children. FEMS Microbiol Lett. 2003;227:249-53.

\section{Submit your next manuscript to BioMed Central and take full advantage of:}

- Convenient online submission

- Thorough peer review

- No space constraints or color figure charges

- Immediate publication on acceptance

- Inclusion in PubMed, CAS, Scopus and Google Scholar

- Research which is freely available for redistribution 